\title{
HVMANITAS
}

\section{A linguagem dos alimentos nos textos bíblicos sentidos para a fome e para a abundância}

\author{
Autor(es): $\quad$ Dias, Paula Barata \\ Publicado por: Faculdade de Letras da Universidade de Coimbra, Instituto de Estudos \\ URL $\quad$ URI:http://hdl.handle.net/10316.2/27939 \\ DOI: $\quad$ DOI:http://dx.doi.org/10.14195/2183-1718_60_11 \\ Accessed : $\quad$ 26-Apr-2023 11:47:38
}

A navegação consulta e descarregamento dos títulos inseridos nas Bibliotecas Digitais UC Digitalis, UC Pombalina e UC Impactum, pressupõem a aceitação plena e sem reservas dos Termos e Condições de Uso destas Bibliotecas Digitais, disponíveis em https://digitalis.uc.pt/pt-pt/termos.

Conforme exposto nos referidos Termos e Condições de Uso, o descarregamento de títulos de acesso restrito requer uma licença válida de autorização devendo o utilizador aceder ao(s) documento(s) a partir de um endereço de IP da instituição detentora da supramencionada licença.

Ao utilizador é apenas permitido o descarregamento para uso pessoal, pelo que o emprego do(s) título(s) descarregado(s) para outro fim, designadamente comercial, carece de autorização do respetivo autor ou editor da obra.

Na medida em que todas as obras da UC Digitalis se encontram protegidas pelo Código do Direito de Autor e Direitos Conexos e demais legislação aplicável, toda a cópia, parcial ou total, deste documento, nos casos em que é legalmente admitida, deverá conter ou fazer-se acompanhar por este aviso.

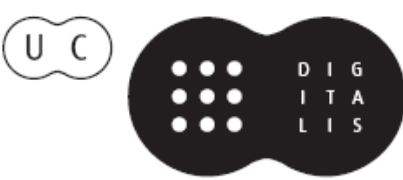


humanitas

\section{Vol. LX}

IMPRENSA DA UNIVERSIDADE DE COIMBRA

COIMBRA UNIVERSITY PRESS 


\title{
A LINGUAGEM DOS ALIMENTOS NOS TEXTOS BÍBLICOS SENTIDOS PARA A FOME E PARA A ABUNDÂNCIA
}

\author{
Paula Barata Dias \\ Universidade de Coimbra \\ pabadias@hotmail.com
}

\begin{abstract}
Resumo
A literatura cristã, particularmente a monástica, sobrevaloriza a limitação dos alimentos como método ascético, e divulgou como positivas algumas estratégias de privação alimentar enquanto fonte de virtude. Esta perspectiva coincide, em larga medida, com o votar dos alimentos à sua condição utilitária, com a depreciação a que geralmente se votam as percepções com origem no gosto, ou com que se considera menor a arte ou a apreciação estética dos alimentos. No entanto, os textos bíblicos estão repletos de referências à alimentação, não só como realidade incontornável do destino da humanidade, mas também como fonte de significado espiritual e místico. Este artigo visa ilustrar a riqueza das referências alimentares contidas na Bíblia, explorar os seus significados e, sobretudo, mostrar como o condicionamento alimentar, não necessariamente pelo vector da privação e da renúncia, faz parte da linguagem espiritual do cristianismo.

Palavras-chave: comida, pão, alimentos, fome, saciedade, abundância, Bíblia, literatura cristã.

\section{Abstract}

The purpose of this article is to redress an imbalance regarding the way Christian literature deals with the subject of food. There are many references to the importance of fasting or dieting in relation to the ascetic way of life and how this is a virtue. This view coincides, largely, with a widespread contemporary scorn for those who have an aesthetic appreciation of food.
\end{abstract}


However, this is a rather one-sided viewpoint as the Bible is also rich in more positive references on the same subject and how it is a source of spiritual and mystical significance. The article explores their meanings and how, not only the denial and renunciation of food is an essential constituent to the spiritual language of Christianity, but also its abundance and indulgence.

Keywords: food, bread, nourishment, famine, abundance, Bible, Christian literature.

$\mathrm{O}$ livro $\mathrm{V}$ das Instituições Cenobíticas de João Cassiano apresenta como título De Spiritu Gastrimargiae "Acerca da tentação da gula". De entre a lista de combates que devem ser conduzidos pelo monge que aspira à perfeição, a saber, pela ordem em que Cassiano os indica, gastrimargia, fornicatio, auaritia, ira, tristitia, acedia, uana gloria, superbia, a gula surge como o primeiro vício a ser dominado'.

O monge marselhês do séc. IV d.C. foi responsável pela divulgação, no Ocidente e na literatura monástica latina, do catálogo dos vícios que ferem o cristão, e em particular o monge enquanto cristão mais exigente. É um motivo já sólido da teorização monástica de língua grega, que graças a Cassiano migrou para a cultura latina e por esta via está presente, até aos dias de hoje, na cultura contemporânea ocidental ${ }^{2}$.

A ordem apresentada no catálogo pressupõe uma leitura gradativa ascendente dos combates. Assim, o sucesso da guerra pela perfeição depende

${ }^{1}$ P. Barata Dias (2006), “O catálogo dos pecados mortais - a sua presença na cultura antiga e contemporânea (I- introdução)", BEC 45: 95-102. A linguagem usada por Cassiano é agónica: elatio "dardo"; "certamen" "combate"; agon "competição", uirus "veneno"; spiritus "espírito"; temptatio "tentação"; daemon "demónio"; uitium "fraqueza" são alguns dos termos usados por Cassiano e na literatura latina.

${ }^{2}$ Sobre as manifestações concretas do tema na história literária antiga, grega e latina, e nas literaturas europeias em línguas vernaculares, ver Richard Newhauser (1993) The Treatise on Vices and Virtues in Latin and the Vernacular, Brepols, Typologie des Sources du Moyen Age Occidental n. ${ }^{\circ}$ VII, 205 pp. Evágrio do Ponto, leitor e discípulo de Orígenes (Capita de diuersis malignis cogitationibus, PG 79, cols 1200-1233; De Octo Vitiosis Cogitationibus, PG 40 cols 1272-1276) é considerado o primeiro autor que sistematizou esta reflexão e a colocou ao serviço da disciplina monástica. Efrém Sírio, no seu Logos Asceticos (Abel do Nascimento Pena, Efrém Sírio. Sua recepção no Ocidente Hispânico, FLUL, 2000), também reflecte sobre o tema. Em Latim, além de Cassiano, outros autores como Martinho de Braga, 
da ordem das batalhas. Sendo a luta pela perfeição monástica progressiva, primeiro devem dominar-se as tentações mais fáceis, ou mais primitivas, aquelas que decorrem da natureza humana enquanto espécie viva dotada, antes de tudo, do instinto da auto-preservação. A gula e a luxúria estão ligadas ao mais necessário dos impulsos que animam as espécies vivas que é o da sobrevivência: alimentar-se e reproduzir-se são pressupostos básicos não negociáveis da vida.

$\mathrm{Na}$ ordenação de Cassiano, há portanto uma evidente interpretação da natureza humana na sua complexidade biológica e funcional, mas também no seu mapa fisiológico, tal como era concebido pelas ciências antigas: primeiro, os combates do ventre (gula e luxúria); depois, os combates do coração, mais ligados às manifestações emocionais (avareza, ira, tristeza); finalmente, os combates do intelecto (vaidade e soberba). Cassiano situa-se numa linha de desenvolvimento espiritual devedora da religiosidade cristã, mas também dos preceitos filosóficos do platonismo, nomeadamente da separação entre o corpo e o espírito, entre o sensível e o inteligível, com valorização dos segundos como fontes do conhecimento autêntico. Assim, são vários os pensadores ascéticos cristãos que encararam com desconfiança as manifestações dos sentidos e mesmo os dados aportados por estes, apresentando um caminho até Deus de progressivo despojamento dos condicionamentos humanos: fome, sono, frio, movimento, estímulos visuais e auditivos, sensibilidade à dor, todas estas barreiras orgânicas do corpo foram testadas como etapas a eliminar pelos que queriam estar próximos de Deus ${ }^{3}$.

Cassiano, como divulgador deste motivo na espiritualidade monástica e no cristianismo em geral, deu voz a uma tendência que ainda é fácil de reconhecer na cultura ocidental, e com alguns reflexos perversos nos

Prudêncio, Eutrópio de Valência, Alberto Magno, Alcuino, Bernardo de Cluny, entre outros, testemunham a popularidade do tema entre a literatura cristã. (Ver R. Newhauser, op. cit. pp. 21-53). O monge e Papa Gregório Magno foi responsável pela transferência deste tema enquanto proposta edificadora exclusiva do público monástico para a moralidade cristã em geral, na sua magistral obra Moralia in Job. Foi também quem fixou o catálogo dos vícios no número de sete, e na ordem que The conhecemos hoje, que inverte a de Pascásio e de Cassiano, da catequese cristã actual sob o nome de sete pecados capitais.

${ }^{3}$ J. Daniélou (1954), Platonisme et théologie mystique: doctrine spirituelle de Saint Grégoire de Nysse. Paris. 
nossos dia e que consiste no desvalorizar da alimentação enquanto comportamento humano. Dominar este impulso é o primeiro dos combates porque implica sacrificar o que de mais primitivo existe no homem. É também o menos dificil, e a vitória sobre ele, conseguida através da sua redução à essência mínima, manipulando as quantidades e as qualidades dos alimentos ingeridos pelo jejum e pela abstinência selectiva, revela um homem apto para combates com adversários mais poderosos e mais dignificantes ${ }^{4}$.

O que é a essênncia da alimentação, qual é o limiar de suporte de vida, o estritamente necessário para garantir a sobrevivência saudável do corpo e a energia necessária ao seu funcionamento? Cassiano, como outros teorizadores monásticos, cristãos, ou membros de outras religiões, incluiu o disciplinar da alimentação - pelos jejuns, pela selecção do tipo de alimentos, pela interdição periódica de determinadas qualidades de alimentos - na sua prática religiosa, garantindo por vários métodos, em regra, não comprometer a premissa da sobrevivência do corpo.

O reduzir da alimentação ao grau zero da sua presença no quotidiano dos comportamentos humanos é um acto complexo, mas não exclusivo da religiosidade antiga, cristã ou outra" : revela por um lado uma "secundari-

${ }^{4}$ Inst. Coen. V, 3, Itaque prinum nobis ineundum certamen est aduersus gastrimargiam, quam diximus gulae esse concupiscentiam, et in primis de ieiuniorum modo et escartum qualitate dicturi... (em tradução nossa) "assim, o primeiro combate que devemos travar é contra a gastrimargia (de gastêr + margeîn "estômago + enfurecer"), que é a concupiscência da gula, e em primeiro lugar falaremos da quantidade dos jejuns e da qualidade dos alimentos...". O princípio da progressividade dos combates aparece bem enunciado em Inst. Coen. V, 10-11, onde se descreve a sequência dos combates: para vencer a luxúria, há que ter derrotado a gula; para vencer a avareza, há que ter dominadas as duas primeiras, e assim progressivamente. Justifica-se então, no final do cap. 11 ...impossibile namque est extingui ignita corporis incentiua, priusquam ceterorum quoque principalium uitionm fomites radicitus excidantur.. " $E$ que é impossível que o fogo que incendeia o nosso corpo seja extinguido se, primeiro que tudo, os estímulos dos vícios principais não forem eliminados pela raiz..."; Quantalibet urbs sublimitate murorum et clausarum portarum firmitate muniatur, posterae unius quanuis paruissimae proditione uastabitur. "Por mais altos que sejam os muros, e por mais sólidas que sejam as portas a protegerem uma cidade, ela será pela traição de um só alçapão secundário, ainda que pequeníssimo, devastada".

${ }^{5}$ Para mencionar os caso mais conhecidos de manifestações religiosas associadas ao condicionamento de práticas alimentares, o pitagorismo pressupunha a 
zação" deste aspecto como condicionador da actividade humana, sobretudo quando motivado por um desejo de aproximação à divindade; mas, por outro lado, a disciplina imposta nos métodos de controlar esta redução não permite obliterar, ou retirar a visibilidade, à importância dos próprios alimentos no curso da vida humana. Estes aspectos apresentam no mundo actual os mesmos contornos paradoxais, que embora estejam despidos de uma normativa e de implicações religiosas, se assumem com a mesma força na sua capacidade de condicionar o comportamento ${ }^{6}$.

adopção de uma dieta vegetariana; o Dionisismo incluía rituais de ingestão de carne crua. $O$ hinduísmo e o budismo, embora nem $\mathrm{em}$ todos os ramos destas antigas religiões tal aconteça, adoptam dietas vegetarianas. $O$ judaísmo e o islamismo têm, além de um calendário de jejuns rituais, uma série distinta para cada um de alimentos interditos.

${ }^{6} \mathrm{~A}$ redução do acto de alimentar-se às exigências determinadas pela biologia e a fisiologia humanas, a disciplina dos jejuns periódicos ou a abstinência de determinados alimentos impõem uma mestria de si próprio, um conhecimento da realidade que pretende domar-se, neste caso da que envolve a escolha e a preparação dos alimentos, que acabam finalmente por trazer para o foco das atenções o próprio objecto que se pretende reduzir, ou repudiar. Assim, todos estamos hoje bem informados quanto à relação entre a dieta e a saúde. Todos conhecemos, por a escola, o médico, os meios de comunicação social nos terem informado, o limiar calórico diário ideal de cada um, de acordo com o sexo, idade e profissão. A pirâmide dos alimentos, ou a proporção correcta das quantidades e qualidades de nutrientes, estão apresentadas com base no princípio do suporte da sobrevivência saudável, que Cassiano também respeitou, ao colocar como limite para os jejuns e abstinência a saúde do corpo. Hábitos sociais instalados como o comer de pé; a comida rápida (a fast food); mesmo as fórmulas milagrosas das dietas sintéticas que promovem a boa forma física, em pílulas ou batidos; as perturbações da anorexia e bulimia; o padrão de beleza ocidental, identificado com a "ausência de gordura"; "baixo peso"; e magreza; a ditadura da boa forma física, são manifestações deste fenómeno que associa o condicionar da alimentação como modo de construir um ideal humano. Michel Lawers, "Santas e anoréxicas: o misticismo em questão", in Jacques Berlioz (1994), Monges e religiosos na Idade Média (Terramar, trad. port. 1996), pp. 219-223, apresenta uma interessante confronto entre o fenómeno contemporâneo ligado ao culto da privação dos alimentos e as manifestações místicas da Idade Média dos que levavam o jejum ao extremo de só se alimentarem das espécies eucarísticas. 
Cassiano evoca o versículo paulino temptatio uos non adprehendit nisi humana "Não vos sobrevém nenhuma tentação que não seja humana"7 para expor a necessidade de, preliminarmente, enfrentar os combates que disciplinam o corpo, antes de merecer a experiência de grauiores pugnae, os combates mais dificeis, os do espírito. Assim, o combate que implica domesticar a ingestão de alimentos e o próprio apetite é o mais humano e o mais carnal dos combates. Mais tarde, disciplinadas e sublimadas as necessidades do corpo, está o homem preparado para provas mais dificeis e mais nobres, as que envolvem o espírito e o intelecto. Vemos que também Cassiano, sem deixar de relegar o alimentar-se para um plano secundário da dimensão humana, não afasta esta dimensão do plano ascético para o homem. De onde vem esta ambivalência na consideração do acto de alimentar-se?

Alimentar-se é, provavelmente, o mais primordial e mais humano dos comportamentos, na medida em que a supressão deste agir é incompatível com a vida. De entre os modos de relação com o exterior proporcionados pelos sentidos de que o homem está dotado, este é, simultaneamente, o menos nobre, mas o mais vital e o mais necessário à mecânica da vida, juntamente com a respiração. Podemos viver sem os estímulos proporcionados pelo sentido da visão, sem a audição, sem o movimento e o sentido do tacto. Porém, privados de água e de alimentos, a morte sobrevém rapidamente. Acresce a esta constatação o facto de o gosto ou o paladar, os sentidos mais directamente ligados ao acto de alimentar-se, implicarem uma apropriação íntima do objecto ingerido ou saboreado que, no limite, o transforma na substância do próprio agente: podemos ver, ouvir, tocar, e mesmo cheirar os objectos do mundo, sem que estes sejam transformados ou destruídos, mas para saborearmos ou para nos alimentarmos, consumirmos e transformarmos fazem parte do processo de apreensão do objecto ${ }^{8}$.

${ }^{7} 1$ Cor 10,13. Apresentamos a nossa tradução para o que é citado por João Cassiano no passo comentado Inst. Coen. V 16. A tradução apresentada pela Bíblia dos Capuchinhos é "Não vos sobreveio tentação alguma que ultrapasse as forças humanas". A versão da Vulgata (Colunga-Turrado, 1946) apresenta o verbo no conjuntivo "Tentatio uos non apprehendat nisi humana" "que não vos sobrevenha nenhuma tentação que não seja humana". Já o texto em Grego (Nestle-Aland, 1898) salvaguarda, para o verbo em causa, quer o aoristo, quer, em aparato, o

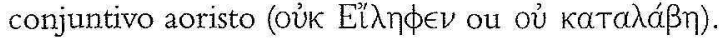

${ }^{8}$ Ann W. Astell ed. (2006), Eating Beauty, the Eucarist and the Spiritual Arts of the Middle Ages. Ithaca, 2, "Taste and See", inicia o seu comentário sobre a estética 
Se retirarmos a reflexão do plano estritamente ditado pelos instintos biológicos, veremos que, ligado a cada um destes sentidos, cuja razão primordial de existir é exclusivamente funcional - a natureza não desperdiça os seus recursos com a criação de inutilidades - está uma dimensão artística e estética, que se desenvolveu e se cultivou na história e na cultura humanas: vemos, em primeiro lugar, para localizar os objectos de que precisamos, mas também para apreciar o céu azul ou a beleza de um quadro; ouvimos para localizar o som de um chamamento, mas também para apreciar uma sinfonia; movemo-nos e somos dotados de tacto para manipular objectos, mas também abraçamos e dançamos. Ingerimos para nos mantermos vivos e com energia, mas fazemo-lo saboreando e degustando, ou seja, desencadeando uma série de processos orgânicos e químicos complexos que proporcionam sensações de bem-estar e de prazer, as quais estão absolutamente presentes na vida diária da generalidade dos homens?

do gosto alertando para a dificuldade em associar este sentido às artes superiores. Cita um sermão de Nicolau de Cusa (sec. XV) dedicado à celebração da festa da Natividade da Virgem Maria, em que este diz: (sic, apud A. Astell ) "And if we pay attention, making use of the more spiritual senses (I. e. a visão e a audição)...thus vision and hearing in different ways comprehend the beautifoul. We do not call a scent a beautifoul, nor a taste, nor anithing that we touch, because those senses (smell, taste, touch) are not so near the ractional spirit; for they are purely bestial and animal. For all properly human senses are nobler than those of brutes, by reason of union with the intellectual spirit." Cita também Hegel "Smell, taste and touch are excluded from the enjoyment of art".

${ }^{9}$ H. R. Schiffman (1990), Sensation and Perception: An Integrated Approach. New York, 156-163. No cap. 4 deste livro, o autor aborda aquilo a que chama de "sensações primárias" (em oposição com as mais elaboradas visão e audição dos primeiros capítulos) como o tacto, o gosto e o olfacto, que estão presentes nas complexas percepções ligadas ao acto de alimentar-se. A. Roberts (2006), Messengers of god. The sensuous side of spirituality, "Thinking about the senses", pp. 5-26; "tasting", pp. 109-128. O paladar, sentido proporcionado pelas papilas gustativas situadas na língua, só capta a sensação de doce, salgado, amargo e ácido. A sensação de quente, frio, líquido, pastoso ou rijo pertencem já ao sentido do tacto proporcionado pela pele. A interacção com o sentido do olfacto é que permite a complexidade de sabores que sentimos ao mastigar os alimentos, acto cuja função não é apenas a de reduzir por acção mecânica os alimientos, mas também a de proporcionar o tempo necessário para sobre eles agir o olfacto. Alimentar-se é, por isso, uma acção que leva tempo. Por isso os alimentos ficam "sem sabor" quando estamos constipados. 
No entanto, temos dificuldade de associar dimensões artísticas ou estéticas claras a esta capacidade de fruição, de tal forma ela se banaliza no comportamento humano: a culinária, a gastronomia, mesmo a arte da perfumaria não fazem parte do catálogo das sete artes, embora estejam presentes no quotidiano banal do nosso dia-a-dia pela produção, conservação e preparação dos alimentos que chegam, em geral, à nossa mesa transformados de um modo que nos dá prazer, ou de que gostamos.

A etimologia e a linguagem corrente reproduzem quer a complexidade fenomenológica do acto de alimentar-se, quer a facilidade com que se registou a transferência de categorias entre a sensação e a cognição, entre o instintivo e o consciente e elaborado. $\mathrm{O}$ que pretendemos dizer exactamente quando usamos o verbo "saber", do verbo latino sapere, que significa "saborear; degustar"? E quando dizemos, por exemplo, que gostamos da Primavera, teremos em mente o significado latino de gustare, "ingerir, deglutir"?; ou quando actualizamos verdadeiros chavões idiomáticos como "gostos não se discutem", ou "é uma questão de gosto", pensaremos na referência subliminar à apreensão através do paladar, ou tão só na complexa paleta de sentidos envolvida na produção do conhecimento e na nossa resposta subjectiva ao mesmo, manifestada sob a forma de juízos ou de opiniões?

Com estas considerações, que decorrem mais de uma observação das realidades quotidianas enquanto tais do que de uma aturada análise teórica, pretendemos de algum modo apresentar uma possível explicação do que consideramos ser um paradoxo que está presente na linguagem da espiritualidade, e concretamente nos textos cristãos, como em Cassiano.

$\mathrm{O}$ aperfeiçoamento espiritual do homem religioso exige-lhe o domínio sobre o acto de alimentar-se, a frugalidade, a abstinência e o jejum, isto é, a redução deste comportamento ao estritamente necessário e funcional. Contudo, este domínio aparece, na ordem dos combates, num lugar secundário, como preliminar em relação aos combates mais graves e mais dificeis,

Ao contrário do olfacto, sentido extremamente sensivel e afectado por várias patologias, o paladar é bastante resistente. Segundo os especialistas, os sentidos do paladar e do olfacto evoluíram como todos os outros na espécie humana, ou seja, para proporcionar uma melhor adaptação ao meio ambiente. Neste caso, o paladar está ao serviço do reconhecimento do que é útil e benéfico para o homem, e que por isso está associado à procura de sensações agradáveis, ou de prazer. 
o que constitui também uma desvalorização da importância do acto em si, apreciação que é, em larga medida, coincidente com a mentalidade do homem moderno.

No entanto, a mesma linguagem da espiritualidade utiliza metáforas e imagens de enorme riqueza que associam o acto de alimentar-se à fruição e à felicidade que resulta do mesmo, legitimando-o como fonte de percepção mística. Do mesmo modo, o acto de alimentar-se aparece como fundamento de rituais e práticas religiosas, que vão desde os sacrificios pagãos até à Eucaristia própria do cristianismo. Finalmente, no próprio texto bíblico, são abundantes, nas suas narrativas, motivos e símbolos ligados à alimentação, aos próprios bens alimentares e à experiência dos extremos, desde a inanição à saciedade, quer como limites da própria humanidade quer como metáforas da superação da mesma.

Conscientes de que esta segunda parte do paradoxo, a que na prática valoriza a presença da linguagem relativa à alimentação e aos alimentos como fonte de significação religiosa, está hoje pouco presente na nossa mentalidade e tem sido menos debatida academicamente, pretendíamos contribuir para a análise do tema através de uma incursão pelos motivos alimentares enquanto integrados na linguagem espiritual e religiosa do cristianismo.

A expulsão de Adão e Eva do paraíso, segundo a narrativa do Gen. 3, foi provocada pela falta original, ao comerem o fruto proibido. Eva, apesar de conhecer a interdição, admira e deseja o fruto de atraente aspecto, antes mesmo de o valorizar pela sua capacidade de abrir a inteligência ${ }^{10}$. Ingerir o fruto proibido não decorre da satisfação do impulso natural da fome (que não existiria no paraíso), mas da apreciação estética da beleza do fruto e do desejo do conhecimento proporcionado pelo fruto que, segundo a serpente, "tornaria quem o ingerisse semelhante a Deus". Do castigo dado aos

${ }^{10}$ Gen. 3, 6 Vidit igitur mulier quod bonum esset lignum ad uescendum, et pulchrum oculis, aspectuque delectabile: et tulit de fructu illius, et comedit deditque uiro suo, qui comedit (Trad. da Bíblia dos Capuchinhos) "Vendo a mulher que o fruto da árvore devia ser bom para comer, pois era de atraente aspecto, e precioso para esclarecer a intcligência, agarrou do fruto, comeu, deu dele ao seu marido, que estava junto dela, e ele também comeu". O excerto sublinhado não surge na Vulgata (Vulg.),

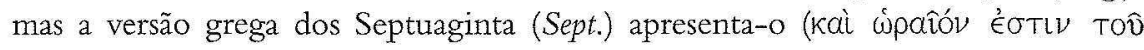

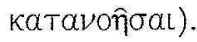


faltosos também faz parte o condicionamento alimentar. A serpente está condenada a rastejar, alimentando-se de terra. Sobre Adão, cai a ameaça da fome, afastada pela disciplina do trabalho ${ }^{11}$.

A gravidade do que está em causa neste acontecimento maior não se limita a haver "menos um fruto no pomar de Deus", e o facto de se terem escrito múltiplas páginas de comentários e exegeses sobre a interpretação deste passo inicial do Génesis, todas atribuindo aos elementos envolvidos na narrativa um carácter simbólico é disso prova. No entanto, é consensual que se trata de uma narrativa mítica sobre as origens, que pretende justificar o sofrimento, a mortalidade, o trabalho e a sucessão das gerações, ou seja, um mito que concentra, numa breve narrativa, o curso observável da vida dos homens.

Após o dilúvio, Noé plantou a primeira vinha e, com os frutos colhidos produziu vinho, com que se embriagou, num relato cuja sequência termina por explicar não só a geração de vários povos do Médio-Oriente, mas também a rivalidade histórica e os conflitos entre eles, fundamentados na maldição que Noé lançou ao seu filho mais novo, Cam, o pai de Canaã, por este o ter surpreendido embriagado e despido na tenda ${ }^{12}$. Também por um prato de lentilhas se alterou a ordem de progenitura entre Esaú e Jacob, filhos de Isaac e netos de Abraão. Jacob repetiu o engodo quando, instigado pela mãe, preparou e serviu ao pai um prato de deliciosos cabritos, fazendo-se passar pelo primogénito, Esaú, o que levou Isaac a abençoar apenas a jacob ${ }^{13}$.

A busca de alimento está na base de algumas migrações relatadas na Bíblia. Já em Canaã, a terra que the tinha sido prometida, Abraão desceu até ao Egipto, levado por "uma grande fome"14. Um novo surto afecta Isaac, o que o leva a fixar-se perto dos filisteus ${ }^{15}$. José, escravo no Egipto, por ter afastado o espectro das fomes cíclicas que atingiam o país graças ao

${ }^{11}$ Gen $614 ; 3$, 19 "comerás o pão com o suor do teu rosto".

${ }^{12}$ Gen. 10 18-27.

${ }^{13}$ Gen. 25, 29 "E disse a Jacob:- Deixa-me comer dessa coisa vermelha, pois estou muito cansado (...) Jacob disse-lhe: - vende-me o direito de progenitura. Esaú retorquiu - Que me importa a mim o direito de progenitura se estou a morrer de fome?".

${ }^{14}$ Gen. $13,10$.

${ }^{15}$ Gen. 26, 1. 
seu dom para interpretar sonhos, recebe os favores do faraó, o que the permite constituir descendência e instalar a família no Egipto ${ }^{16}$.

O Livro do Êxodo narra o regresso dos descendentes destes Judeus à terra prometida, conduzidos por Moisés. As oito pragas que assolaram o Egipto, desde as águas do Nilo convertidas em sangue até aos gafanhotos, são, na Bíblia, descritas sobretudo pela sua capacidade de gerarem sede, fome e doença entre os egípcios ${ }^{17}$. Anunciada a décima praga, o extermínio dos primogénitos egípcios, o Senhor instrui Moisés sobre o modo de proceder naquela noite fatal. Este procedimento instituiu, entre os Judeus, o ritual da Páscoa: será imolado um cordeiro sem defeito, em cada casa. Com o seu sangue serão pintadas as ombreiras das casas, mas a sua carne deverá ser assada e totalmente consumida nessa noite, acompanhada de pães ázimos e de ervas amargas. Nada deve ser guardado para o dia seguinte, porque será o dia da partida. É assim testada a fé dos Judeus na promessa da libertação ${ }^{18}$.

Por várias vezes, já durante a errância pelo deserto, Deus colocou à prova a confiança do seu povo através do condicionamento alimentar. No segundo mês de permanência no deserto, levantaram-se os primeiros murmúrios contra Moisés e Araão. Temendo sucumbirem por causa da fome, lamentam ter abandonado "as panelas de carne e o pão que comiam à vontade" do Egipto. Quando a ansiedade pela falta de alimentos e pelo risco da sede os atinge, e se levantaram murmúrios entre os Judeus, o Senhor fez cair sobre o deserto uma chuva de maná, o qual "se parecia com a semente de coentro, era branco e tinha o sabor de bolo de mel", e fez brotar água do rochedo de Horeb ${ }^{19}$.

Sustentaram-se deste alimento de origem divina durante os quarenta anos de errância no deserto, mas a sua entrega ao povo obedecia a uma

16 Gen. 41. Gen 42. Os sonhos do faraó interpretados por José incluem também metáforas alimentares: sete vacas gordas devoradas (deuorauerunt eas) por sete vacas magras, sete espigas viçosas absorvidas (deuorantes omnem) por sete espigas raquíticas. Os laços com a sua família de origem são reatados quando esta fome se estende aos povos vizinhos, levando-os a procurar socorro na prosperidade do Egipto.

${ }^{17}$ Ex. 8-10.

${ }^{18}$ Ex. 12.

${ }^{19}$ Ex. 16, 31...quod erat quasi semen coriandri album, gustusque eius quasi similae cum melle. Ex. 17. 
noção de compromisso entre Deus e o homens que implica o saciar-se, confiando na entrega quotidiana do bem alimentar, mas não ultrapassar esse limite. Açambarcar (cada família recolhe uma determinada quantidade para um dia), e reservar para o dia seguinte jam contra as instruções divinas, e revelaram-se inúteis. Assim, em diversos momentos os Judeus são vencidos pela tentação de recolher mais do que a quantia autorizada para aprovisionarem para o dia seguinte, mas no final do dia, as medidas recolhidas eram iguais para todos, e o maná, enchendo-se de vermes, torna-se impróprio de ser consumido ${ }^{20}$.

A monotonia da dieta também constitui um foco de tensão entre o programa de Deus e as expectativas dos homens: novamente se fizeram levantar murmúrios entre os errantes, "atacados por desejos desordenados" 21 .

"- Quem nos dará carne para comer? Lembramo-nos do peixe que comíamos no Egipto, sem nos custar nada, dos pepinos, dos meloes, dos alhos porros, das cebolas e dos alhos. Agora, temos a garganta seca. Falta-nos tudo. Nada mais temos do que maná. (...) - Onde encontrarei came para todo este povo que me assedia com as suas lágrimas dizendo:-Dá-nos came para comer!

Não está em causa o poder nutritivo do maná, pois a errância no deserto durou décadas, nem o seu sabor agradável, pois as comparações usadas evocam sensações de doçura e a macieza evocadas por dois dos alimentos mais populares e apreciados na Antiguidade, a saber, o mel e o azeite $^{22}$.

Deus pune os descontentes proporcionando-lhes uma refeição excessiva e descontrolada do alimento desejado, a carne, cuja ingestão não tinha sido proibida, desde que determinada pela disciplina divina ${ }^{23}$. Assim, na noite anterior à da queda do primeiro maná, as mesmas codornizes tinham

${ }^{20}$ A errância de Moisés no deserto é narrada nos livros do Êxodo, do Levítico e dos Números. Ex. 16, 17-20.

${ }^{21} \mathrm{Nm} .11$ 4-9. Vulg. "flagrauit desiderio"; Sept.'E

${ }^{22}$ Ex. 16, 31; Nm 11, 7 O maná é descrito como pão ou bolo "O maná era semelhante ao grão de do coentro e tinha o aspecto de bdélio (tipo de pedra preciosa). O povo dispersava-se para o recolher e depois moía-o em moinhos ou pisava-o com almofarizes; cozia-o numa panela e fazia bolos com ele. Tinha o sabor das tortas feitas com azeite..." 
aparecido no acampamento, e o povo pôde comê-las, dentro do estrito limite temporal fornecido por Deus ${ }^{24}$.

Já havíamos vislumbrado esta restrição do tempo aquando da última noite passada pelos judeus no Egipto. Estes foram então advertidos para nada reservar para o dia seguinte pois iriam partir. Neste passo agora citado, pode estar associada à ideia da errância, da viagem do povo pelo deserto, que não se compadecia com o carregar de reservas alimentares excessivas. Mas, numa leitura mais profunda, está também em causa a fé nas promessas de Deus e a capacidade de se abandonar à providência divina, numa manifestação de humildade e de confiança diante do que é superior. Está em causa, em suma, a ideia do compromisso e da aliança celebrada entre Deus e o seu povo.

A mesma mensagem está presente no NT, particularmente na célebre exortação de Cristo sobre a simplicidade de vida das aves e dos lírios do campo $^{25}$, mas também na formulação precisa da primeira oração, o Pai Nosso, em que os homens são ensinados a pedir apenas o necessário, "o pão de cada dia"26.

${ }^{23} \mathrm{Nm}$. 11, 19 O relato bíblico destaca a imoderação e o desejo de reservar para o futuro, o que revela a falta de confiança nas promessas de Deus. "O Senhor dar-vos-á carne a comer. E não a comereis durante um dia ou dois, nem durante cinco dias, dez dias ou vinte dias, mas durante um mês inteiro, a tal ponto que ela vos saia pelas narinas e vos cause náuseas..."; Caíram então codornizes sobre o acampamento, todos as apanharam e comeram-nas, ocupando-se a "expô-las em volta do acampamento". A interpretação do excerto que acabámos de citar ganha em clareza com a Vulg. et siccauerunt eas per gyrum castrorum, corroborada por idêntica versão nos Sept. Secar a carne é mais do que "expô-la", implica uma intenção de a conservar para o futuro. Nm. 11, 33, "A carne estava ainda entre os dentes, ainda não tinha sido engolida, quando a cólera do Senhor se inflamou".

${ }^{24}$ Ex. 1618 "esta tarde o Senhor dar-vos-á carne para comerdes, e amanhã pão com fartura (...) Ex. 16, 12 Esta tarde, ao anoitecer, comereis carne, e amanhã saciar-vos-eis de pão..."

${ }^{25}$ Lc 12 22, 24, 29: "não vos preocupeis quanto à vossa vida, com o que haveis de comer; nem quanto ao vosso corpo, com o que haveis de vestir (...) Reparai nos corvos; Não semeiam nem colhem; não tem dispensa nem celeiro, e Deus sustenta-os (...) Não vos inquieteis com o que haveis de comer ou de beber, nem andeis ansiosos, (...) pois o vosso pai sabe que tendes necessidade delas".

${ }^{26}$ Lc. 11, 3 "dai-nos em cada dia o pão da nossa subsistência"; Mt. 6, 11 "O pão nosso de cada dia nos dai hoje", na formulação que ainda agora usamos. 
Parece-nos óbvio que o que está em causa nesta narrativa não é tanto a ementa proposta por Deus ou preferida dos homens, ou sequer uma história da dieta alimentar dos antigos judeus. A linguagem e os motivos evocados que recolhemos apenas dos primeiros livros da Bíblia e em passos estritamente narrativos, todos do campo semântico da alimentação, assumem, tal como acontecera no livro do Génesis a propósito do fruto interdito aos homens, uma dimensão metafórica e simbólica coerentes. A narrativa explora a tensão entre a fome, a saciedade, e a abundância como metáforas da própria capacidade de obediência dos homens a Deus, e da qualidade do compromisso e da confiança instalada entre as duas instâncias.

Deus faz sempre uma promessa de abundância, ligada à expectativa de felicidade, vivida num jardim paradisíaco "de saborosos frutos para comer", ou numa terra prometida "país onde corre o leito e o mel, de frutos abundantes" 27 . Mas os modos de atingir esta plenitude passam pela obediência a determinadas regras cuja gramática é a da moderação: resistir à ingestão do fruto proibido, não consumir tudo o que se vê, não reservar para o dia seguinte, isto é, não ultrapassar os limites definidos, em cada compromisso, por Deus. Esta moderação não surge, contudo, como um fim em si, mas antes como um método para alcançar a humildade e a sintonia com os planos de Deus.

A mesma gramática está presente no Novo Testamento, particularmente nos Evangelhos, nas narrativas de alguns episódios da vida de Jesus e mesmo nas parábolas, em que o Reino dos Céus surge poeticamente evocado como um reino de abundância e de saciedade alimentar, um banquete e uma celebração no qual não tem lugar o jejum periódico e ritual das tradições judaicas ${ }^{28}$.

Vulg. panem nostrum quotidianum da nobis hodie; panem nostrum supersubstantialem da nobis hodie. O pedido formulado é complexo, e assenta em várias restrições: dá-nos o pão nosso (e não o dos outros) de cada dia (o que basta para um dia) hoje (e não amanhã, o que obriga a renovar o pedido diariamente).

${ }^{27}$ Gen. 2, 9; Nm. 13, 27.

${ }^{28}$ Mt. 9 14-15 "Porque é que nós e os fariseus jejuamos e os Teus discípulos não jejuam? - Porventura podem os companheiros do esposo estar tristes enquanto o esposo está com eles?”. Também Mc 2 18-22. Lc 6 33-39 A crítica à periodicidade do jejum praticado pelos judeus é feita nos Evangelhos (por exemplo Lc 6 1-4). As Epístolas e os Actos registam ocasiões de maior conflito em relação aos númerosos interditos alimentares judaicos, sobre o que Cristo não se pronuncia. 
A parábola da boda do filho do rei é apresentada como "semelhante ao reino dos céus", em que muitos são convidados e não só recusam como maltratam os mensageiros, enquanto outros, menos óbvios, acedem ao convite $^{29}$. O reino dos céus é também comparado ao pequeno grão de mostarda que, semeado, se converte na maior árvore do horto, aprazivel para todos, ou à pequena quantidade de fermento que basta para levedar toda a massa ${ }^{30}$. É ainda semelhante a uma rede que recolhe peixe em abundância, que os pescadores seleccionam já na praia ${ }^{31}$. Os apóstolos são comparados ao sal da terra, com as propriedades que este elemento apresentava na Antiguidade, ou seja, a de permitir a conservação e a salubridade dos alimentos e a de temperar ${ }^{32}$.

A parábola bem conhecida do filho pródigo está toda construída em cima destes eixos de sentido: é a fome que motiva o filho perdido a desejar o regresso a casa do pai, e este recebe-o de braços abertos, com um banquete tão faustoso que desperta críticas no outro filho que sempre the tinha sido leal ${ }^{33}$. As Bem-Aventuranças, verdadeiro testamento de Jesus dado aos seus ouvintes, tornam legítimas as grandes preocupações dos homens, e mostram reconhecer que, entre estas a fome ocupa um lugar maior, e é para os despojados do conforto dos alimentos que se dirigem as palavras, formuladas em linguagem antitética, mas que curiosamente associam a ideia da superação da fome à ideia de justiça. Ou seja, as duas realidades têm de coexistir num mundo bem ordenado ${ }^{34}$.

${ }^{29}$ Mt 22 1-14. Lc 14 15-24.

${ }^{30} \mathrm{Mt} 13$ 31-33. Em comum entre estas imagens está a ideia da multiplicação, do crescimento a partir de recursos limitados e da abundância de alimentos.

${ }^{31} \mathrm{Mt} 13,47-48$.

${ }^{32}$ Mt 513.

${ }^{33}$ Lc 151132.

${ }^{34} \mathrm{Lc} 621$ "Bem aventurados vós, os que agora tendes fome, porque sereis saciados" e Lc 625 "ai de vós, os que estais agora fartos, porque haveis de ter fome". Em Mt 5 1-12, a formulação não parece referir-se à fome fisica, mas o vocabulário empregue restaura a metáfora alimentar aplicada à realidade mais abstracta que é a justiça: "Bem aventurados os que têm fome e sede de justiça, porque serão saciados". Vulg. Beati qui esuriunt et sitiunt iustitiam quoniam ipsi

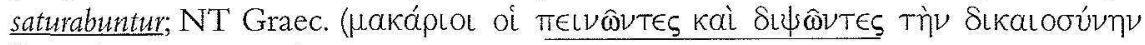

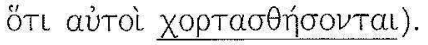


Jesus Cristo iniciou a sua vida pública nas bodas matrimoniais de Caná, e o seu primeiro milagre resolveu objectivamente uma situação de carência de vinho que ameaçava o sucesso do festim ${ }^{35}$. Em dois momentos diferentes Jesus se apiedou da multidão que o seguia, expostos à fome, e realiza multiplicações milagrosas de pão e de peixe, com que sacia a multidão ${ }^{36}$. É na celebração da Páscoa judaica, em redor de uma mesa, que Cristo institui a sua Igreja e celebra a primeira Eucaristia, na véspera de sofrer a Paixão ${ }^{37}$.

$\mathrm{O}$ acto de comer e beber, estando Cristo sujeito às mesmas necessidades de todos os homens, é justamente usado como sinal claro da humanidade que Cristo partilha com os homens. Tendo sentido fome, procura figos numa figueira à beira do caminho, e não os encontrando, amaldiçoa a dita árvore, que seca imediatamente, o que deixa os discípulos surpreendidos com o seu poder ${ }^{38}$. Assim, revela-se, Ressuscitado em corpo e espírito, aos seus discípulos, partilhando com eles alimentos. $\mathrm{Na}$ agonia da cruz, algumas das Suas últimas palavras são para se queixar de sede ${ }^{39}$.

Finalmente, a própria Eucaristia, instituída como um ritual de central importância na vida espiritual do cristão, acenta sobre a simbologia do banquete solene que reúne, em partilha, os fiéis a Deus. $O$ modo como nasceu na vida cristã remete para um concretismo quase chocante e escandaloso para os não $\operatorname{cristãos}^{40}$, e dessa capacidade de abalar consciências

${ }^{35}$ Jo 2 1-10.

${ }^{36}$ Mt 14, 15-21; Mt 15 32-38 "todos comeram até à saciedade, e com o que sobrou encheram sete cestos bem cheios".

${ }^{37}$ Mt 26 17-29; Mc 14, 12-25; Lc 22 7-30; Jo 13 1-32.

${ }^{38}$ Mt 21 18-19. Mc 11 12-14.

${ }^{39}$ Lc 24, 30, com os discípulos de Emaús. Lc 24 42, diante dos onze "Tendes aí alguma coisa que se coma? Deram-Lhe uma posta de peixe assado, e tomando-a, comeu-a diante deles". Mc 16, 14 "Apareceu finalmente aos próprios onze quando estavam à mesa". Jo 21, 12-13 Jesus aparece aos discípulos pela terceira vez, participa numa faina especialmente abundante (a ponto de as redes ameaçarem romper-se), após a que prepara o peixe e come com eles. "Tenho sede. (...) Tudo está consumado" As últimas palavras na cruz, segundo Jo 1928.

${ }^{40} \mathrm{O}$ ritual Eucarístico parece estar na base das acusações de canibalismo e de infanticídio feitas aos cristãos na Época das perseguições. 
estava ciente Jesus, quando se apresentou como "o pão da vida", a ser dado em alimento aos que Nele acreditam. Nos primeiros séculos do cristianismo a Eucaristia, à letra "a Boa Graça", era designada por coena Dominica ou mensa Domini (kuriakon deîpnon); sacrificium (thusía), oblatio, fractio panis (klásis tou ártou) ou simplesmente synaxis, termos que permitem associar quer a alimentação e convívio que se encontram em redor de um mesa de festa.

Nenhum destes termos restaura a ideia de moderação ou de privação. Essa dimensão literal do acto de "comer Cristo" nas espécies consagradas e a suspeita de esta ingestão poder ter levado, objectivamente, ao saciar de uma fome fisica, foram vividas pelos primeiros cristãos, a ponto de o apóstolo Paulo ter tido de alertar a comunidade de Corinto para a necessidade de depurar o ritual. A fome do corpo deve ser saciada na casa de cada um, diz ele ${ }^{41}$.

À ideia da saciedade, que decorre da ingestão de alimentos suficientes legitimada na Eucaristia, acresce toda a linguagem mística construída, em segunda instância, sobre esta, que evoca as sensações de prazer e felicidade proporcionados pela doçura do alimento consumido.

Evocamos apenas o exemplo do v. 9 do S1 33 Gustate et uidete quoniam suauis est Dominus", traduzido na liturgia cristã actual para "saboreai e vede como o Senhor é bom", um verso de significado complexo, que, se por um lado indicia um convite expresso ao apreciar das obras da criação "saboreai e vêde os bens que o Senhor vos proporciona", por outro lado pode remeter para a própria fruição proporcionada pela comunhão sagrada, isto é "senti profundamente como Deus é felicidade". Não deve ser ainda ignorada a associação entre o acto de degustar e de ver, os dois dependentes de sentidos físicos não só distintos, como valorizados de modo diferente, mas que aqui convergem para produzir a mesma experiência sinestésica de bem estar. Ou seja, a alimentação, nas suas dimensões de saciar a fome e de proporcionar prazer, ocorre simultaneamente com a apreciação visual da mesma realidade que é ingerida.

${ }^{41} 1$ Cor 1118 27: "Ouço dizer que quando vos reunis há desarmonias entre vós (...) Deste modo, quando vos reunis não o fazeis para comer a ceia do Senhor, pois cada um se apressa a tomar a sua própria ceia; e enquanto uns passam fome, outros se fartam. Porventura não tendes casas para comer e beber? Ou desprezais a Igreja de Deus e quereis envergonhar aqueles que nada têm? 
De algum modo, quem saboreia Deus, vê Deus e, durante o processo, pode sentir, ou conhecer a sua beleza e bondade. Poderemos portanto, interpretar esta associação entre o saborear e o ver como formas particulares de potenciar uma determinada forma de conhecimento místico.

Dos exemplos citados, retirados do texto de primeira referência para os cristãos, podemos constatar a sólida presença da linguagem e de metáforas que remetem para o campo semântico da alimentação e da importância desta na vida dos homens. $O$ facto de a alimentação estar presente como instância de referência metafórica deve-se, pensamos nós, ao reconhecimento tácito por parte dos autores dos textos de que, para estes atingirem os seus fins, a linguagem adoptada teria de ser eficaz, isto é próxima e familiar aos anseios do receptor. Acresce ainda o facto de a presença destes temas na Bíblia contrariarem, na sua funcionalidade como motivos literários ou espirituais mas também na sua dimensão concreta, qualquer desvalorização da alimentação como parte fundamental do próprio definir do homem enquanto tal, pelo que teremos de encarar atitudes como a de Cassiano como uma construção teórica posterior da literatura cristã e uma entre as interpretações possíveis das fontes cristãs.

Em alguns dos episódios relatados, particularmente os de cunho histórico, no AT sobretudo, esta realidade constitui-se na própria essência da narração. Os escritores, ao valorizarem a alimentação como motor da acção dos povos, não fazem mais do que reconhecer a prosaica realidade da aventura humana de sempre, que começa, em primeiro lugar, pela luta pelos alimentos, pela fuga à fome e à morte que ela arrasta. Por isso, associar o reino dos céus a um banquete ou à abundância de alimentos, ou apresentar a união com Deus através de um ritual que implica alimentar-se, fazem sentido no quadro dos anseios do homem comum. Esta linguagem foi entendida pelos homens antigos certamente, tal como o é pelos homens de hoje.

\section{Bibliografia}

Bíblia Sagrada, Difusora Bíblica (Missionários Capuchinhos), Lisboa, 11² ed, 1984.

Biblia Vulgata (1994): A. Colunga L. Turrado eds., Biblioteca de Autores Cristianos 14, Madrid, $9^{2}$ ed., 1946.

Nouum Testamentum Graece (1993): Nestle Aland eds., Deutsche Bibelgesellschaft, Stuttgart, $2^{a}$ ed., 1979. 
Septuaginta (2004): Alfred Rahlfs ed., Deutsche Bibelgesellschaft, Stuttgart, $3^{\mathrm{a}}$ ed. 1935.

F. P. Dutripon (1986), Bibliorum Sacrorum Concordantiae, Georg. Olms Verlag, Hildesheim-New York.

J. Cassien, Institutions Coenobitiques (Inst. Coen.) (1965): J. Claude Guy ed. e trad., Sources Chrétiennes n. ${ }^{\circ} 109$, Ed. Du Cerf., Paris.

Dictionnaire de Sirrtualité, Ascetique et Mystique (DSp), Beauchesne, Paris, 1957, fasc. 24, s.v. J. Chatillon, "Dulcedo Dei", cols 1777-1795.

Dictionnaire d'Archéologe Chrétienne et de Liturgie (DACL), F. Cabrol et H. Leclercq, Paris, Letousey et Ané, 1924, s.v. "Eucharistie", t. 5; cols cols 681-692; "Pain", t. 13 cols 436-460.

Dictionnaire de la Brble (DBibl), F.Vigouroux ed. Patris, Letousey et Ané 1912, s.v. "pain", t. 41951-1959; "Famine" t. 2 cols 2173-2176.

A.W.Asteln ed. (2006), Eating Beauty. The Eucarist and the Spiritual Arts of the Middle Ages. Ithaca.

R. Futton (2006), "Taste and see that the Lord is sweet" (ps. 33.9) The flavor of God in the Monastic West", The Journal of Religion 86, 2, The University of Chicago Press, pp. 169-204.

H. R. Schiffman (1990), Sensation and Perception: An Integrated Approach. New York.

R. Newhauser (1993), The Treatise on Vices and Virtues in Latin and the Vernacular, Brepols, Typologie des Sources du Moyen Age Occidental n..$^{\circ}$ VII. 